Scientific Journal Warsaw University of Life Sciences - SGGW

Problems of World Agriculture volume 17 (XXXII), number 4, 2017: 182-192

DOI: 10.22630/PRS.2017.17.4.94

Lukasz Kryszak $^{1}$, Jakub Staniszewski ${ }^{2}$

Poznań University of Economics and Business

\title{
The Elasticity of Agricultural Income in the EU Member States Under Different Cost Structures
}

\begin{abstract}
The aim of this paper was to determine whether the EU countries which vary in terms of their cost structure in agriculture, differ also with regard to the influence of capital-labour ratio and land supply per worker on labour profitability. It was assumed that data concerning the presence and character of those differences can contribute to better understanding of the nature of agricultural development in the EU countries. The main sources of data used in this paper were the Economic Accounts for Agriculture (Eurostat) and the FAOStat database. The study covered the period of 20042014. In the article it was shown that agriculture in the EU countries is varied in terms of cost structure, and in the cluster II, including mostly the countries of the so-called "new" EU, intermediate consumption is of relatively larger significance for their cost structure. In the countries of the "old" $\mathrm{EU}$ an important role is played by the depreciation of buildings and external services. Stronger influence of capital-labour ratio on the payment to the factor of labour was observed in the cluster II countries. In those countries, increasing capital expenditures was a more efficient strategy to increase income.
\end{abstract}

Key words: agricultural income, cost structure, European Union, income elasticity

JEL Classification: O13, Q10, Q14

\section{Introduction}

European agriculture displays a strong relationship between the endowment of the factors of production and their productivity. Hence, beneficial relationships between individual production factors determine high productivity in agriculture (Baer-Nawrocka, Markiewicz, 2013). From a theoretical point of view, labour productivity is a predictor of labour profitability. Productivity depends, in turn, on the value of capital-labour ratio and land supply per worker (Bezat-Jastrzębowska, Rembisz, 2015). The former factor is particularly important, which has been proven empirically (cf. Gołaś, 2010). Capital-labour ratio is the capital equipment per unit of labour, where capital can be understood from a resource-based view (e.g. total assets), as well as from a stream-based view. In this latter view, capital is usually understood as agriculture-related costs. In this case the volume of intermediate consumption, and sometimes the amount of depreciation or other costs (e.g. interest, rents, compensation of employees), is used. The strength of the cost approach is supported by the fact that assets of an agricultural holding tend to be partially nonproductive (e.g. empty utility buildings).

\footnotetext{
${ }^{1}$ MA, Department of Macroeconomics and Agricultural Economics, Poznań University of Economics and Business, A1. Niepodległości 10,61-875 Poznań, e-mail: lukasz.kryszak@ue.poznan.pl; https://orcid.org/0000-0001-8660-9236

${ }^{2}$ MA, Department of Macroeconomics and Agricultural Economics, Poznań University of Economics and Business, Al. Niepodległości 10,61-875 Poznań, e-mail: jakub.staniszewski@ue.poznan.pl; https://orcid.org/0000-0001-8074-0911
} 
Agriculture-related costs are a complex category and are the subject of numerous studies. Two approaches competing in the course of research into costs in agriculture can be named; the synthetic approach, involving estimating costs (and then income) of all activities in an agricultural holding, and the analytical approach, where a stronger emphasis is put on estimating precise costs and profits of particular directions of production. Currently, the synthetic approach is prevalent (Ziętara, 2009).

Difficulties in cost analysis are associated with the use of private means of production in agriculture, because such means often are not actually paid. An increasing degree of interrelation between agricultural holdings and the market, which is, as a matter of fact, an indicator of the modernization of agriculture, leads to an increase in external financing in the capital structure of a holding (Gołębiewska, 2010). According to Kulawik (1996), agriculture is characterized by difficulties in generating equity, which means it has to be supported with external capital. This results in a change in the capital (cost) structure; however it is not a negative phenomenon, because agricultural holdings using external financing may take advantage of the financial leverage effect (Szymańska, 2009). It can be stated that the more external factors (actually paid ones) there are in cost structure, the more accurate are income accounts. Otherwise, the amount of income recorded in databases is distorted by the fact that the estimated value of one's own means of production involved is not subtracted. This phenomenon inspires attempts at designing methods of estimating the cost of using one's own means of production, including the valuation of one's own work and the cost of using private arable land (Goraj, Mańko, 2011). The authors of this article assume that agriculture in the EU displays varied structures of operating costs among the member states. This variation within microstructures constitutes a quantifiable reflection of qualitative changes occurring in the economy (Kukuła, 2010, p. 16). The final verifier of the adequacy of a structure, however, is the economic result, which can be represented by the generated income (Goddart et al., p. 485). It is determined by, among others, the relation between resource relationship and their elasticity. In the paper elasticity of agricultural income is assessed. It is defined as a change in income which occurs with the change of resource relationships. For example, if the elasticity equals 0,5 it means that with the $1 \%$ increase in the inputs relationship, agricultural income increases for $0,5 \%$. This situates our research among the others concentrated on finding determinants of agricultural income. Many determinants have been identified as so far, including contract farming (Nadolny, Dzatora, Nguyen, 2015), socio-cultural and education factors (Panda 2015), agricultural policy (Hansen, Teuber, 2011, Severini, Tantari, 2013) or trade distortions (Anderson, Martin, Van der Mensbrugghe, 2006). The conducted research is about to extend the list above for determinants of a structural nature. However, structures in agriculture can be assessed in many dimensions. Earlier studies sought the impact of relations in agricultural production factors (Baer-Nawrocka, Markiewicz, 2013), diversification in produced commodities (Goletti, 1999), agrarian structure (Manjunatha et al., 2013; Czyżewski, Staniszewski, 2016) or structure of agricultural support (Czyżewski, Smędzik, 2017). This paper is going to expand this research agenda, by evaluating the impact of another dimension of agricultural structures - the cost structures. According to our best knowledge similar research on a macroeconomic scale has not been conducted as so far. The aim of this paper was to determine whether the EU countries which vary in terms of their cost structure in agriculture, differ also with regard to the influence of capitallabour ratio and land supply per worker on labour profitability. The data concerning the 
presence and character of those differences will contribute to a better understanding of the nature of agricultural development in the EU countries, by defining its determinants.

\section{Data and methods}

The study conducted can be divided into two stages. The first one involved dividing the EU countries into groups, the criterion being the cost structure of agricultural activity. On the basis of data from the Economic Accounts for Agriculture (EAA) three dimensions of this structure can be distinguished: I - general cost structure, II - intermediate consumption structure, III - the structure of consumption of fixed capital (the components of particular dimensions are listed in detail in Table 2). Those structures were characterized by averaged data from the period 2004-2014. The degree of similarity among the structures was calculated with a formula proposed by Kukuła (2010, p. 29):

$$
v_{p l}=\frac{\sum_{i=1}^{k}\left|\alpha_{i}-\beta_{i}\right|}{2}
$$

where, $\alpha$ is the vector of state a's structures, $\beta$ is the vector of state b's structures.

To make the comparison, this coefficient uses the so-called Manhattan distance ${ }^{3}$, and its measure is normalised - it ranges from 0 to 1 , where 0 indicates maximum correspondence while 1 indicates maximum divergence. Through estimations three distance matrices were obtained, values of which were then averaged. Particular structure dimensions were assigned the following weight: I -0.5 ; II -0.25 ; III -0.25 , which reflect their importance. They were selected in such a way, since dimensions II and III constitute an analytical continuation of the components of dimension I. The synthetic distance matrix was then used in a cluster analysis, performed with Ward's method ${ }^{4}$. The statistical significance of the differences between two sample means in each type of cost were tested using Student's $t$-test (if the variable in each cluster had normal distribution) or nonparametric Mann-Withney $U$ test (in other cases). The assumption of homogeneity of variance of variables between the clusters was evaluated using the Levene's test and the Brown-Forsythe test. If the assumption was rejected we also used a non-parametric approach.

In the second stage of the study the elasticity of changes in agricultural income (payment to the factor of labour) in response to the changes in capital-labour ratio and the supply of land per labour unit were estimated. The clusters of countries indicated in the first stage were used. The elasticity was estimated with panel regression models ${ }^{5}$. The first panel included 12 countries over the period of 11 years, the other 13 countries over the period of

\footnotetext{
${ }^{3}$ This name stems from the method of calculating the distance necessary to move from one spot in a city to another when the only possible movement is along straight lines intersecting at right angles (Stanisz, 2007, p. 116).

${ }^{4}$ In this method, the distance between points is calculated with the analysis of variance approach. It is aimed at minimizing the sum of squared deviations within clusters. This method is used as a very effective one, although it promotes little clusters (Stanisz, 2007, p. 122).

${ }_{5}^{5}$ Panel regression is a method to analyze two-dimensional (typically cross-sectional and longitudinal) panel data. The data are usually collected over time and over the same individuals and then a regression is run over these two dimensions.
} 
11 years (2004-2014). Luxembourg and Latvia were excluded from analysis due to the lack of data on the structure of consumption of fixed capital (in EAA they were entirely classified as "other"). The original values of the dependent variable were replaced with moving averages covering 3 observed periods between 2005 and 2013 and 2 observed periods in 2004 and 2014. This procedure was chosen because incomes in agriculture are subject to fluctuation on a yearly basis due to their dependence on the global economic situation and weather conditions, which cannot be accounted for by changes in expenses alone. A stream-based (cost-based) approach to capital was applied. Since agricultural holdings often have considerable assets uninvolved directly in production, a cost-based approach to capital appears to be justified and it has been used in other studies within the field of agricultural economics (Niezgoda, 2009a; Niezgoda, 2009b; Nowak, Wójcik, Krukowski, 2015). In the aforementioned papers, capital was understood as a sum of costs, which in this case includes the cost of hiring workers, interest and rent. This approach is justified when microeconomic data (e.g. FADN) are used, and the income of agricultural entrepreneurs is modelled (in the FADN database the relevant category is net income, while in Eurostat - entrepreneurial income) $)^{6}$. In a macroeconomic approach, which considers the entire supply of land and labour, a more adequate income category is value added (optionally factor income, including subsidies), which is generated also by people who are not owners of a holding and land, which does not belong to a farmer. Then, there is no need to include the cost of land and labour in the capital flow. When panel-type data are used, the sum of income can be modelled in relation to supplies spent (a Cobb-Douglas-type function) or payment to one of the factors of production can be modeled in relation to the relations among the remaining factors of production. In this article the latter approach was taken. A relative weakness of using a traditional Cobb-Douglas-type function in macroeconomic studies is the little variation in inputs in agricultural production over short periods. It particularly applies to land supplies in highly developed countries. Definitions of variables used in the models are presented in Table 1.

In order to estimate the parameters of the function for the payment to the factor of labour, raw input data were logarithmised and a panel regression model was estimated. The adequacy of chosen models (least squares model, fixed effects model, random effects model) was tested with the Breusch-Pagan test and the Hausman test with statistical significance at the 0.05 level (Kufel, 2011). In all cases the most accurate model specification was the random effects model (Random effects-RE). The models were estimated using the PCSE (Beck-Katz) robust standard errors procedure. Therefore, the model equation was constructed as follows:

$$
\begin{aligned}
& \ln (\text { AGRICULTURAL INCOME } \\
& \left.\quad+\beta_{2}\right)=\beta_{0}+\beta_{1} * \ln \left(\text { C }\left(\text { TAPITAL } / A W U_{i t}\right)+v_{i}+\varepsilon_{i t}\right.
\end{aligned}
$$

where: $v_{i}$ is random drawings from a given probability distribution, $\varepsilon_{i t}$ is net random error.

\footnotetext{
${ }^{6}$ When net income is modelled, it is sometimes possible to include the entire supply of land and labour used by agricultural holdings in explaining variables, assuming "methodological rationality of farming families or management" (Niezgoda 2009b).
} 
Table 1. Definitions and sources of variables used in the analysis

\begin{tabular}{|c|c|c|}
\hline Variable & Description & Source \\
\hline Agricultural income & $\begin{array}{l}\text { Factor income as a measure of income } \\
\text { generated by all production factors in } \\
\text { agriculture. The formula is: net value } \\
\text { added at basic prices + other subsidies on } \\
\text { production minus other taxes on } \\
\text { production. Net value added is calculated } \\
\text { by subtracting depreciation and total } \\
\text { intermediate consumption from the value } \\
\text { of agricultural output. }\end{array}$ & $\begin{array}{l}\text { Economic accounts for agriculture } \\
\text { - values at real prices in euro, } \\
\text { chain linked volume }(2010) \\
\text { [aact_eaa04] }\end{array}$ \\
\hline Capital & $\begin{array}{l}\text { Total sum of total intermediate } \\
\text { consumption and depreciation. }\end{array}$ & $\begin{array}{l}\text { Economic accounts for agriculture } \\
\text { - values at real prices in euro, } \\
\text { chain linked volume (2010) } \\
\text { [aact_eaa04] }\end{array}$ \\
\hline Labour (AWU) & $\begin{array}{l}\text { Total Annual Work Units (thousands). } 1 \\
\text { AWU corresponds to the work performed } \\
\text { by one person who is occupied on an } \\
\text { agricultural holding on a full-time basis. } \\
\text { It may differ between member states but } \\
\text { usually it is circa } 2000 \text { h per year. }\end{array}$ & $\begin{array}{l}\text { Agricultural Labour Input } \\
\text { Statistics [aact_ali] }\end{array}$ \\
\hline $\begin{array}{l}\text { Total agricultural area } \\
\text { (TAA) }\end{array}$ & $\begin{array}{l}\text { Total agricultural area in thousands of } \\
\text { hectares. }\end{array}$ & FAOStat/Inputs/Land \\
\hline
\end{tabular}

Source: Author's own elaboration based on Economic Accounts for Agriculture, Eurostat and FAOStat.

The research methods applied in the paper lead to conclusions about the influence of the cost structure on the agricultural income in an indirect way. They test whether in groups of countries where these structures are significantly different, the income elasticity if the capital-labour ratio and land supply per worker is also different. These elasticities are treated as specific intermediary variables. The justification for such a methodology is the complexity of the cost structure in agriculture. Without the "a priori" adoption of a certain benchmark, it is not possible to transform this data into a synthetic indicator, expressed on a nominal scale, which would allow for their direct use in regression models. On the other hand, placement of all elements of the cost structure in the regression equation was impossible due to the limited number of observations.

\section{Cluster analysis results}

The cluster analysis conducted (Fig. 1.) allows for distinguishing two groups of countries and two outliers - Latvia and Luxembourg. This accounts for their separate clustering.

The remaining 25 countries were divided into two clusters. In the first one, 10 out of 12 countries are "old" EU countries. The remaining two are Bulgaria and Hungary. Cluster II contains most of the "new" member states (which joined the EU after 2004), with the exceptions of Portugal, Spain, Ireland and Belgium. A detailed breakdown of the structures in particular clusters is presented in Table 2. 


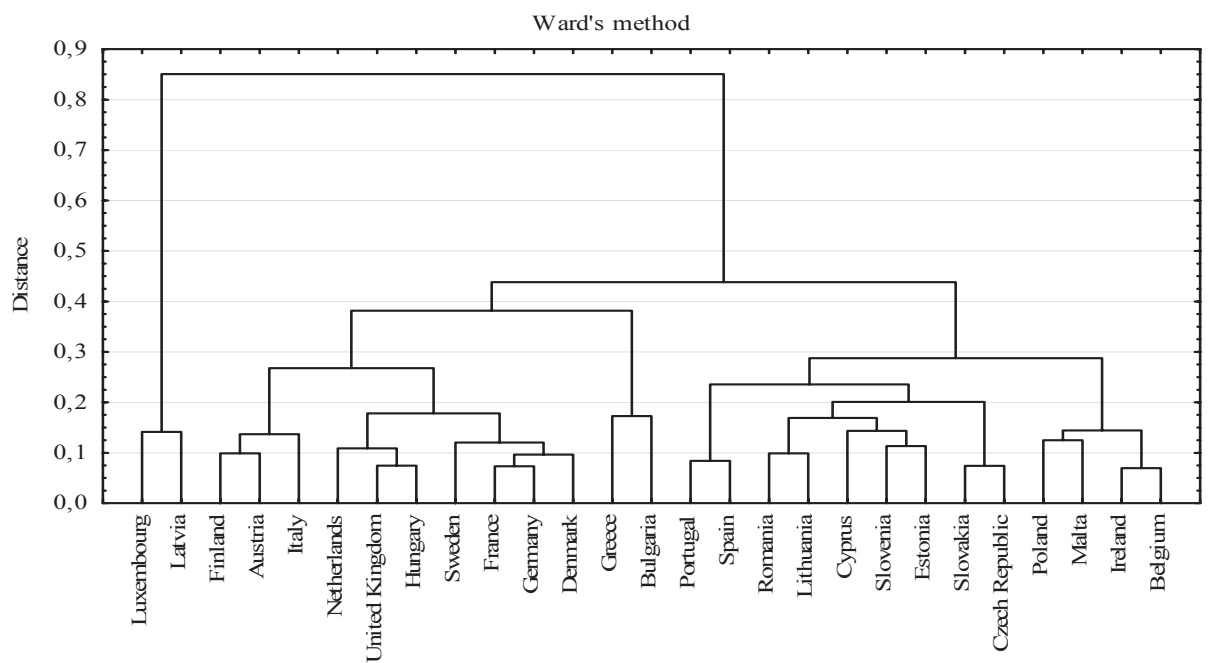

Fig. 1. The results of cluster analysis of EU Member States based on the structure of costs in agriculture sector in years 2004-2014

Source: Author's research based on Eurostat data (access: March 31st 2017).

When it comes to general cost structure (Dimension I), in both cases intermediate consumption is prevalent, but its percentage share was higher by 6 p.p. in Cluster II. At the same time, Cluster I exhibited a higher percentage of consumption of fixed capital (by 5 p.p.). Both differences were statistically significant. The structure of intermediate consumption (Dimension II) is also convergent but to a lesser extent. Costs of feedstuffs play a dominant role, however their percentage share is much higher in Cluster II (by 9 p.p.). In Cluster I, however, costs of agricultural services (5 p.p. more) and other goods and services (3 p.p. more) were more important. The first two differences were statistically significant. Regarding the structure of consumption of fixed capital (Dimension III), Cluster I is characterized by a higher share percentage of depreciation of buildings, while Cluster II - by a higher share percentage of plantations. In the case of this cluster, however, a restriction concerning outliers must be made. In Cluster I, Greece is a problematic case, where all consumption costs are counted as depreciation of agricultural equipment. In Cluster II, the percentage share of plantations is inflated by Spain and Portugal, which diverge from other EU countries in this respect. Nevertheless, the division allowed for identifying two groups of countries. In the first one, agriculture is better equipped with fixed capital, in particular buildings, and external services are used more often. In the other group the most important agricultural cost are current expenses, mostly feedstuffs. 
Table 2. Characteristics of identified groups

\begin{tabular}{|c|c|c|c|c|c|c|}
\hline \multirow{2}{*}{$\begin{array}{l}\text { Dimen- } \\
\text { sion }\end{array}$} & \multirow{2}{*}{ Types of costs } & \multicolumn{2}{|c|}{ Cluster I } & \multicolumn{2}{|c|}{ Cluster II } & \multirow{2}{*}{$\begin{array}{l}\text { t-Student } \\
\text { or Mann- } \\
\text { Withney U } \\
\text { Test** }\end{array}$} \\
\hline & & $\begin{array}{c}\text { Mean (in } \\
\%)\end{array}$ & $\mathrm{CV} *$ & $\begin{array}{c}\text { Mean (in } \\
\%)\end{array}$ & $\mathrm{CV}^{*}$ & \\
\hline \multirow{6}{*}{$\mathbf{I}$} & $\begin{array}{l}\text { (1) total intermediate } \\
\text { consumption }\end{array}$ & 65 & $10 \%$ & 71 & $8 \%$ & $\mathbf{0 , 0 3 5}$ \\
\hline & (2) fixed capital consumption & 17 & $32 \%$ & 12 & $39 \%$ & $\mathbf{0 , 0 3 5}$ \\
\hline & (3) compensation of employees & 10 & $29 \%$ & 12 & $40 \%$ & 0,222 \\
\hline & (4) other taxes on production & 1 & $86 \%$ & 1 & $95 \%$ & 0,384 \\
\hline & $\begin{array}{l}\text { (5) rents and other real estate } \\
\text { rental charges to be paid }\end{array}$ & 4 & $31 \%$ & 2 & $53 \%$ & 0,001 \\
\hline & (6) interest paid & 3 & $67 \%$ & 2 & $61 \%$ & 0,221 \\
\hline \multirow{11}{*}{ II } & (7) seeds and planting stock & 5 & $29 \%$ & 5 & $39 \%$ & 0,412 \\
\hline & (8) energy; lubricants & 13 & $35 \%$ & 13 & $29 \%$ & 0,532 \\
\hline & (9) fertilisers and soil improvers & 7 & $33 \%$ & 7 & $41 \%$ & 0,834 \\
\hline & $\begin{array}{l}\text { (10) plant protection products, } \\
\text { herbicides, insecticides and } \\
\text { pesticides }\end{array}$ & 4 & $36 \%$ & 4 & $46 \%$ & 0,710 \\
\hline & (11) veterinary expenses & 3 & $46 \%$ & 3 & $47 \%$ & 0,684 \\
\hline & (12) feedstuffs & 34 & $14 \%$ & 43 & $19 \%$ & 0,004 \\
\hline & (13) maintenance of materials & 6 & $23 \%$ & 5 & $37 \%$ & 0,165 \\
\hline & (14) maintenance of buildings & 2 & $54 \%$ & 3 & $48 \%$ & 0,192 \\
\hline & (15) agricultural services & 8 & $29 \%$ & 3 & $59 \%$ & $\mathbf{0 , 0 0 0}$ \\
\hline & $\begin{array}{l}\text { (16) financial intermediation } \\
\text { services indirectly measured }\end{array}$ & 2 & $54 \%$ & 2 & $92 \%$ & 0,221 \\
\hline & (17) other goods and services & 16 & $28 \%$ & 13 & $50 \%$ & 0,131 \\
\hline \multirow{4}{*}{ III } & $\begin{array}{l}\text { (18) fixed capital consumption: } \\
\text { equipment }\end{array}$ & 62 & $27 \%$ & 62 & $8 \%$ & 0,943 \\
\hline & $\begin{array}{l}\text { (19) fixed capital consumption: } \\
\text { buildings }\end{array}$ & 32 & $46 \%$ & 27 & $34 \%$ & 0,356 \\
\hline & (20) plantations & 2 & $137 \%$ & 7 & $127 \%$ & 0,183 \\
\hline & (21) other & 3 & $134 \%$ & 4 & $127 \%$ & 0,568 \\
\hline
\end{tabular}

Group I: Finland, Austria, Italy, Netherlands, United Kingdom, Hungary, Sweden, France, Germany, Denmark, Greece, Bulgaria;

Group II: Portugal, Spain, Romania, Lithuania, Cyprus, Slovenia, Estonia, Slovakia, Czech Republic, Poland, Malta, Ireland, Belgium;

* CV- coefficient of variation;

** p value lower than 0,05 means that one can reject the null hypothesis that there are no stastically significant differences between mean of given variable between clusters. Non-parametric approach was used in variables: 4 , $5,6,8,12,13,16,20,21$.

Source: Research conducted by the authors based on Eurostat data (access: March 31st 2017). 


\section{Elasticity analysis results}

In the second stage of the study, a function of income (payment to the factor of labour) in relations to capital-labour ratio and supply of land per a unit of labour was estimated (Table 4). The first step was to estimate the function including both explained variables; the next step involved using only the variable which was statistically significant. Descriptive characteristics of the levels of used variables in both clusters of countries are presented in Table 3.

Table 3. Descriptive statistics of the variables used in models

\begin{tabular}{l|cccccc}
\hline \multicolumn{1}{c|}{ Types of costs } & \multicolumn{3}{c}{ Cluster 1} & \multicolumn{3}{c}{ Cluster II } \\
& Mean & SD** & CV*(\%) & Mean & SD** & CV* $(\%)$ \\
\hline Agricultural income/AWU (thousand EURO) & 22.63 & 11.96 & 53 & 12.64 & 9.00 & 71 \\
Capital/AWU (thousand EURO) & 57.67 & 43.28 & 75 & 24.22 & 23.21 & 96 \\
UAA/AWU & 27.50 & 15.62 & 57 & 17.93 & 11.86 & 66 \\
\hline
\end{tabular}

* CV- coefficient of variation,

** SD- standard deviation.

Source: Research conducted by the authors based on Eurostat and FAOStat data (access: 31.03.2017).

In Cluster I (including most of the so-called EU15 countries), the average payment to the factor of labour in the 2004-2014 period amounted in EUR 22.63 thousand, while in Cluster II it was EUR 12.6 thousand, which is $44 \%$ less. Cluster II was characterised by a higher coefficient of variation, which points to a higher heterogeneity of the panel. There were also observable differences in capital-labour ratio. In Cluster I, it was EUR 57.67 thousand in capital value per each AWU, while in Cluster II - only 24.3 thousand per AWU ( $57.3 \%$ less). In both clusters the values of capital-labour ratio were widely varied among individual countries and in studied years, however bigger differences were observed in Cluster II. Cluster I was also characterised by a more profitable ratio of factor of land to factor of labour. There were 27.5 ha per each person employed full-time, while in Cluster II it was 17.9 ha (nearly $35 \%$ less). The differences between the clusters within this variable were relatively lower, similarly to the variation within individual clusters, which is accounted for by a lower coefficient of variation.

In both clusters, the direction of influence of land to labour ratio on payment to the factor of labour was consistant with the predictions, however the lack of statistical significance at the level of at least 0.1 does not allow for a substantive interpretation of the regressor value. Another fact pointing to the lack of the significance of this variable is that including only one explaining variable in a model does not negatively influence the explanatory power of the model (cf. $\mathrm{R}^{2}$ values). No statistical significance of the influence of land to labour ratio on incomes observed in the model can partially stem from little variation in this variable in the studied period. According to the Herlemann Stamer model (1963), the process of land concentration (an improvement in the ratio of the factors of land and labour) is the last important stage of the agricultural development cycle.

The estimated models indicate an important role of the stock of capital in relation to available labour force in explaining payment to the factor of labour. In Cluster I, a $1 \%$ increase in capital to labour ratio led to a $0.66 \%$ increase in payment to the factor of labour. When it comes to Cluster II, a $1 \%$ increase in capital to labour ratio resulted in payment to 
the factor of labour increasing by $0.81 \%$. It can be concluded then, that agricultural income in the countries of Cluster II reacted stronger to changes in the stock of capital in relation to available labour force. Additionally, in the case of models for Cluster II, a better $\mathrm{R}^{2}$ fit value was obtained. In all estimated models, within variance was lower than between variance and theta value was close to one, which means that the models explain the variation in the explained variable more accurately within individual countries than among countries.

Table 4. The results of agricultural income per AWU model estimation

\begin{tabular}{|c|c|c|c|c|}
\hline \multirow{2}{*}{ Variable } & \multicolumn{2}{|c|}{ Cluster I } & \multicolumn{2}{|c|}{ Cluster II } \\
\hline & (1) & (2) & (3) & (4) \\
\hline Number of observation & 132 & 132 & 143 & 143 \\
\hline constant & $\begin{array}{c}0.474 \\
(0.191)\end{array}$ & $\begin{array}{c}0.491 \\
(0.151)\end{array}$ & $\begin{array}{l}-0.098 \\
(0.187)\end{array}$ & $\begin{array}{l}-0.046 \\
(0.166)\end{array}$ \\
\hline CAPITAL / AWU & $\begin{array}{c}0.652 * * * \\
(0.067)\end{array}$ & $\begin{array}{c}0.661 * * * \\
(0.042)\end{array}$ & $\begin{array}{c}0.757 * * * \\
(0.071)\end{array}$ & $\begin{array}{c}0.810^{* * *} \\
(0.046)\end{array}$ \\
\hline TOTAL UAA/AWU & $\begin{array}{r}0.015 \\
(0.89)\end{array}$ & - & $\begin{array}{c}0.078 \\
(0.082)\end{array}$ & - \\
\hline Type of effects & $\mathrm{RE}$ & RE & $\mathrm{RE}$ & RE \\
\hline Hausman test $p$ value & 0.74 & 0.60 & 0.07 & 0.69 \\
\hline Within variance & 0.012 & 0.012 & 0.010 & 0.010 \\
\hline Between variance & 0.058 & 0.052 & 0.123 & 0.126 \\
\hline Theta & 0.865 & 0.858 & 0.913 & 0.913 \\
\hline F Test & $94.98 * * *$ & $198.63 * * *$ & $153.70 * * *$ & $306.95 * * *$ \\
\hline$R^{2}$ & 0.60 & 0.60 & 0.68 & 0.69 \\
\hline Akaike criterion & $-1,367$ & $-1,627$ & 124,521 & 104,927 \\
\hline
\end{tabular}

$*, * *$, and $* * *$ denote $10 \%, 5 \%$, and $1 \%$ significance levels, respectively.

Source: Research conducted by the authors based on Eurostat and FAOStat data (access: March 31st 2017).

Cluster II includes most of the "new" EU countries, where capital saturation is relatively lower, which results in a stronger reaction of incomes to an increase in the stock of capital. In the cost structure of agricultural holdings in cluster II, intermediate consumption, in particular feedstuffs, is of relatively higher importance. A smaller role is played by costs related with depreciation and external means of production (agricultural services, interest, rent). After 2004, most countries of Cluster II adopted the strategy of classic intensification, understood from the perspective of high importance of intermediate consumption in overall costs. A capital-intensive growth path of incomes brought about satisfactory results in those countries, at least in comparison with countries with higher level of capital to labour saturation and a cost structure shifted toward the use of external means of production. The growing share of expenditure on external means of production and fixed capital did not translate into higher elasticity of income. 


\section{Conclusions}

On the basis of the information included in this article the following should be stated:

- Cluster analysis based on variation in cost structure led to the identification of two groups largely overlapping with the division into "old" and "new" member states;

- Cluster I is made up mostly of the countries of the "old" EU, where agriculture is better equipped with fixed capital, in particular buildings, and farmers are more likely to use external services. In the countries of Cluster II current agricultural expenses, in particular feedstuffs, were more important;

- In the Cluster I countries in the studied period observably higher payment to the factor of labour was noted. The relations between individual means of production were also observably more profitable. Both capital-labour ratio and land-labour ratio was higher in Cluster I, while the differences involved mostly the former relation;

- In the countries with the cost structure in which current expenses, that is intermediate consumption (Cluster II) played a more important role, payment to the factor of labour reacted more strongly to changes in capital-labour ratio. Most likely, those countries adopted the strategy of material-consuming intensification, which, due to a relatively low level of agricultural development in that area, lead to relatively large benefits. Because the changes in the relations in supply of land and available workforce in agriculture were too slow, land-labour ratio did not significantly influence payment to the factor of labour in either cluster.

\section{Literature}

Anderson, K., Martin, W., Van der Mensbrugghe, D. (2006). Distortions to world trade: Impacts on agricultural markets and farm incomes. Applied Economic Perspectives and Policy, 28(2), 168-194.

Baer-Nawrocka, A., Markiewicz, N. (2013). Relacje między czynnikami produkcji a efektywność wytwarzania w rolnictwie Unii Europejskiej. Journal of Agribusiness and Rural Development, 3(29), 5-16.

Bezat-Jarzębowska, A., Rembisz, W. (2015). Wprowadzenie do analizy inwestycji, produktywności, efektywności i zmian technicznych w rolnictwie. Instytut Ekonomiki Rolnictwa i Gospodarki Żywnościowej - Państwowy Instytut Badawczy.

Czyzewski, A., Staniszewski, J. (2016). Zastosowanie regresji panelowej dla oceny produktywności i dochodowości w rolnictwie krajów Unii Europejskiej po 2005 roku. Roczniki Naukowe Ekonomii Rolnictwa i Rozwoju Obszarów Wiejskich, 103(3), 7-21.

Czyżewski, B., Smędzik-Ambroży, K., (2017) The regional structure of the CAP subsidies and the factor productivity in agriculture in the EU 28, Agricultural Economics - Zemedelska Ekonomika, 63(4), 149-163.

Goddard, E., Weersink, A., Chen, K., Turvey, C.G. (1993). Economics of Structural Change in Agriculture. Canadian Journal of Agricultural Economics/Revue Canadienne D'agroeconomie, 41(4), 475-489.

Goletti, F. (1999). Agricultural diversification and rural industrialization as a strategy for rural income growth and poverty reduction in Indochina and Myanmar. MSS Discussion Paper No. 30.

Gołaś, Z. (2010). Wydajność i dochodowość pracy w rolnictwie w świetle Rachunków Ekonomicznych dla Rolnictwa. Zagadnienia Ekonomiki Rolnej, (3), 19-42.

Gołębiewska, B. (2010). Struktura majątkowa i finansowanie działalności w gospodarstwach rolniczych o zróżnicowanych powiązaniach z otoczeniem. ZN SGGW Ekonomika i Organizacja Gospodarki Żywnościowej, 81, 241-250.

Goraj, L., Mańko, S. (2011). Model szacowania pełnych kosztów działalności gospodarstw rolnych. Zagadnienia Ekonomiki Rolnej, 3(328), 28-58.

Hansen, H., Teuber, R. (2011). Assessing the impacts of EU's common agricultural policy on regional convergence: sub-national evidence from Germany. Applied Economics, 43(26), 3755-3765.

Herlemann, H.-H., Stamer, H. (1963). Rolnictwo w dobie technicyzacji. Państwowe Wydawnictwo Rolnicze i Leśne, Warszawa. 
Kufel, T. (2011). Ekonometria: Rozwiązywanie problemów z wykorzystaniem programu GRETL. Wydawnictwo Naukowe PWN

Kukuła, K. (red.) (2010). Statystyczne studium struktury agrarnej w Polsce. PWN, Warszawa

Kulawik, J. (1996). Finansowe problemy strategii rozwoju rolnictwa. Strategiczne problemy rozwoju polskiego rolnictwa. IERiGŻ, Warszawa.

Manjunatha, A.V., Anik, A.R., Speelman, S., Nuppenau, E A. (2013). Impact of land fragmentation, farm size, land ownership and crop diversity on profit and efficiency of irrigated farms in India. Land Use Policy, 31, 397-405.

Nguyen, A.T., Dzator, J., Nadolny, A. (2015). Does contract farming improve productivity and income of farmers?: A review of theory and evidence. The Journal of Developing Areas, 49(6), 531-538.

Niezgoda, D. (2009a). Zróżnicowanie dochodu w gospodarstwach rolnych oraz jego przyczyny. Zagadnienia Ekonomiki Rolnej, 318(1), 24-37.

Niezgoda, D. (2009b). Uwarunkowania rentowności gospodarstw rolnych zróżnicowanych pod względem ich wielkości ekonomicznej. Roczniki Nauk Rolniczych Seria G, 96, 155-165.

Nowak, A., Wójcik, E., Krukowski, A. (2015). The changes in productivity of production factors in commercial farms in Poland in 2004 and 2012. Acta Scientiarum Polonorum. Oeconomia, 14(3), 105-115.

Panda, S. (2015). Farmer education and household agricultural income in rural India. International Journal of Social Economics, 42(6), 514-529.

Severini, S., Tantari, A. (2013). The effect of the EU farm payments policy and its recent reform on farm income inequality. Journal of Policy Modeling, 35(2), 212-227.

Stanisz, A. (2007). Przystepny kurs statystyki z zastosowaniem STATISTICA PL na przykładach z medycyny. Tom 3. Analizy wielowymiarowe. StatSoft, Kraków.

Szymańska, E. (2009). Struktura kapitału w gospodarstwach trzodowych o różnej wielkości ekonomicznej. ZN SGGW Ekonomika i Organizacja Gospodarki Żywnościowej, 76, 41-51.

Ziętara, W. (2009). Rachunek kosztów w przedsiębiorstwach rolniczych w teorii i praktyce. Journal of Agribusiness and Rural Development, 2 (12), 303-309. 